\title{
Commodities in Economics: Loving or Hating Complexity
}

\author{
M. Shahid Alam, Department of Economics, Northeastern University, \\ Boston, MA, USA \\ nurzangi@gmail.com
}

\begin{abstract}
A review of economic thought since the sixteenth century reveals two streams of economic discourse, dirigisme and laissez-faire. Starting with the mercantilists, dirigiste approaches to economics embrace the real-world complexity of commodities that often differ greatly in attributes that are growth- and rentaugmenting. Most importantly, this means that free trade is likely to be polarising: it concentrates growth- and rent-augmenting commodities in countries that already enjoy a head start in these commodities. Advanced countries, therefore, support laissez-faire, while lagging countries tend to support dirigisme. In order to rationalise their laissez-faire stance, advanced countries began developing a new economic discourse that strips commodities of their complexity. The foundations for this ideological reconstruction of economics were first laid by Adam Smith; this process eventually reached its climax with the neoclassical economists who stripped commodities down to one attribute: their capital intensity. In opposition to this laissez-faire economics, other writers, supportive of the interests of lagging countries, brought complexity back into their economic discourse; they argued that lagging countries had a fighting chance of catching up to advanced economies only by indigenising a growing array of growth- and rent-augmenting commodities.
\end{abstract}

Keywords: commodities, complexity, mercantilism, Physiocracy, classical, neoclassical

\section{Introduction}

"Some tender money to me; some invite me;

Some other give me thanks for kindnesses;

Some offer me commodities to buy..." (Shakespeare) ${ }^{1}$

How have different schools of economic thought over the past five centuries dealt with the complexity of real-world goods and services that are exchanged on markets: commodities for short? ${ }^{2}$

Commodities in the real world are complex. They possess multiple attributes - in production, consumption and tradability - that often vary across different commodities and classes of commodities. It may be expected, therefore, that the behaviour of markets will differ depending on the attributes of commodities that are traded on them. Consequently, there have emerged within economics several specialties that study markets in particular classes of commodities, such as agricultural economics, labour economics, financial economics, real estate economics and transportation economics. However, these specialties will not concern us here.

\footnotetext{
${ }^{1}$ Comedy of Errors, IV. iii. 6.

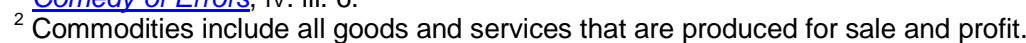


Instead, we will examine the manner in which various writers on the economy have, over the past half a millennium, incorporated commodities into their discourse when dealing with two overarching questions that are central to determining the government's policy stance on the economy. First, what are the conditions under which all markets, individually and simultaneously, attain unique and stable equilibria that also correspond to an efficient allocation of resources? Secondly, do the patterns of specialisation resulting from the free operation of markets affect an economy's growth rate, income distribution, state formation, military power, the aptitudes of its population, its legal institutions, and levels of civilisation more generally?

Although this paper sets itself tasks that appear too ambitious for an essay, they are in fact quite tractable once we recognise a fundamental dichotomy in much of the economic discourse since the $16^{\text {th }}$ century. One set of economic theories embraces the real-world heterogeneity of commodities, while a second set of theories proceeds to homogenise them by stripping them of their real-world complexity. This dichotomy paves the way for exploring several questions of fundamental importance to understanding the economic thought, policies and history of the past five centuries. What are the economic, political, military and institutional consequences of these two divergent approaches to the economy? What are the imperatives that motivate them; and what are the writers and countries that support them? We explore these and other questions.

\section{Commodities, Divergence and Dirigisme}

"Owing to increasing returns in processing activities (in manufactures) success breeds further success and failure begets more failure" (Kaldor, 1981, p. 331).

It may help to preface our discussion with an intuitive look at some implications of commodity attributes for growth and economic policies. ${ }^{3}$

Consider two polar situations. In the first case, all commodities are identical in their growth- and rent-augmenting effects (GREs), say, because they are characterised by constant returns to scale and the absence of external economies. In the event, the patterns of specialisation - determined under free trade - will have no consequences for growth. It is immaterial for a country's growth prospects whether it specialises in raw cotton or designer clothes. In fact, any attempts to change this specialisation - the result of market forces alone will be counterproductive since this will cause efficiency losses that will both lower incomes and direct investments into the 'wrong' channels.

In the second case, consider economies that produce a range of goods with rising GREs: $\mathrm{C} 1, \mathrm{C} 2, \mathrm{C} 3, \mathrm{C} 4, \mathrm{C} 5, \mathrm{C} 6{ }^{4}{ }^{4}$ The growth prospects are likely to be higher in Country $\mathrm{A}$ that specialises in C4, C5 and C6 compared to Country B that specialises in C1, C2 and C3. Further, growth and rising exports in Country A may deepen its existing comparative advantage in $\mathrm{C} 4, \mathrm{C} 5$ and $\mathrm{C} 6$, making it harder for Country $\mathrm{B}$ to catch up. It may even be the case that Country $A$ - because of its richer endowment of knowledge, skills, and technology spillovers from existing industries - may succeed in producing $C 3$ at lower cost than Country B. All this will tend to widen the development gap between countries A and B.

At this stage, what are Country B's chances of catching up to Country A? At some

\footnotetext{
${ }^{3}$ In the interests of simplicity, we exclude the variable effects of commodities on power, laws, institutions, attitudes, the sciences and the liberal arts.

${ }^{4}$ The GREs of a commodity depend on its economies of scale, external economies, use of skills (technical, managerial, marketing), opportunities for innovation and creativity, market power, and the demands it makes on physical and intellectual infrastructure.
} 
point, as wages in the two countries diverge, declining relative wages in Country B may allow it to retain its comparative advantage in existing commodities, and possibly gain comparative advantage in C4. Alternatively, if Country B does not wish to wait forever to be rescued from growing divergence, it may begin to implement policies to reverse this divergence. Among other things, it may offer various combinations of time-sensitive production, export, research and educational subsidies to firms that venture into $\mathrm{C} 4$, and progressively extend these subsidies to C5 and C6; encourage skilled workers from country A to emigrate to country B; offer incentives to family-owned firms in Country $A$ to relocate with their owners to Country $B$; engage in industrial espionage to transfer technology from Country A to Country B; encourage their own citizens to move to country A to acquire their more advanced skills and then lure them back with higher wages and/or appeals to patriotism.

Not to be naïve, these options may not be open to Country B. Even if it can muster the political will to move the economy upstream, this path may be blocked by more advanced countries. Almost certainly, Country A and others in the same camp will use their coercive and soft power - flowing from their wealth, diplomacy, control over global finance, media, and, ultimately a more powerful military - to block Country A's challenge to their comparative advantage in $\mathrm{C} 4, \mathrm{C} 5$ and $\mathrm{C} 6$. In the event, polarisation may become impossible to reverse.

\section{Mercantilism}

"The power of industry is such that there is no silver mine or gold mine in New Spain and Peru that can be compared to it, and the duties on the commerce of Milan are worth more to the Catholic King than the mines of Zacatecas and Jalisco" (Botero, 1613[2012], p. 45).

"[Manufacturing] is a mine more fruitful of gain, riches, and plenty, than those of Potosi" (Uztariz, 1724[1752] $]^{5}$.

What do the writings of the mercantilists - starting in the late $16^{\text {th }}$ century - reveal about their understanding of the nature of commodities? ${ }^{6}$

Influenced by classical Greece, the Renaissance writers recognised a fundamental distinction between Nature and Art and the relations between these two. ${ }^{7}$ In the theories of Plato and Aristotle, the arts are classified under two criteria: the manner in which they imitate nature and their end uses. One set of arts cooperates with nature to "assist and perfect them;" examples of these are medicine, farming and education. A second set of arts, including architecture and carpentry, uses principles learned from nature to produce results not found in nature, such as houses and furniture. In addition, there are the arts that copy appearances of nature (the mimetic arts) and others that copy the principles of justice from nature (the speculative arts of philosophy and legislation) (Close, 1971, pp. 164, 170 and 174). Although this taxonomy contains the germs of a three-fold division of the economy into primary, secondary and tertiary sectors, the classical thinkers did not seem to be interested in the practical consequences of the arts for the economy or power.

\footnotetext{
${ }_{6}^{5}$ Quoted in Reinert and Reinert (2011, p. 8).

${ }^{6}$ Although we reject Adam Smith's characterisation of Mercantilism as a unified system of thought about the economy, we recognise significant similarities in the ideas and policies proposed by mercantilist writers. The contributors to Magnusson's (1993) edited volume on mercantilism also take this view.

${ }^{7}$ Nature consists of the four elemental forces - earth, air, water and fire - their powers of regeneration, and the principles that underlie change and motion in the cosmos. Art is human activity, man working with or upon nature to produce new configurations that meet human needs not directly fulfilled by Nature (Close, 1969, p. 467; and Close, 1971, pp. 163, 167)
} 
In classical Greek thought, Art is inferior to Nature. The arts imitate nature for practical uses and entertainment, and work on material drawn from Nature; to the extent that they deviate from Nature, the arts of politics, ethics and law are 'unreal' or false (Close, 1971, p. 14). In the sixteenth century, however, some Western thinkers were already re-evaluating the significance of the arts under the influence of advances unfolding in the sciences, navigation, shipping, manufacturing and military technology. In 1605, Francis Bacon, in The Advancement of Learning, writes disapprovingly of the view that art is 'merely an assistant to nature, having the power to finish what nature has begun, to correct her when leaping into error...but by no means to change, transmute or fundamentally alter nature' (Margaret, 1986, pp. 8-9). More emphatically, he writes elsewhere that Art not only completes what nature begins, but also possesses the power to alter nature 'radically and shake it to its depths'. In the apt phrase of Sophie Weeks, 'infinite malleability is an essential feature' of matter. Already, some Renaissance thinkers were convinced that human ingenuity could endlessly shape and reshape the material it obtains via agriculture, forestry, fishery and mining (Weeks, 2007, p. 142).

Arguably, these insights into the powers of Art were inspired by growing contacts of the backward parts of Western Europe with the superior commerce, manufactures, shipping and military technology of the leading Italian cities, such as Venice, Milan and Florence. Well before the late sixteenth century, when this contrast between Art and Nature began to receive scholarly attention, practical men and statesmen in the backward parts of Europe understood that the Italian cities owed their wealth and power to their manufactures, commerce and shipping. The rise of the Hanseatic League - the alliance of traders from the ascendant centres of commerce in northern Germany - and, later, Holland, offered additional evidence of the power of commerce and manufactures to generate wealth.

Thus it is in backward England, starting in the late thirteenth century, that we observe the first tentative attempts at using the powers of the government in support of domestic traders and manufactures. ${ }^{8}$ These interventions in support of British commerce began on a small scale with Edward I (1272-1307), who lowered the duty for English traders in the import trade; they were "significantly extended" by Edward III (1333-1360), and 'systematised' by Richard II (13771399) who sought to break the commercial monopoly of the Hanseatic League (Hunt, 2003, pp. 31-32). Although these policies were not always effective, Edward I, together with other mercantilist measures, expelled several foreign enterprises from England; Edward III encouraged the growth of an indigenous woollen industry by supporting immigration of Flemish weavers to Norfolk, banning the export of raw wool, and demanding that Englishmen wear cloth woven in England (Cunningham, 1889, pp. 201-2). He also introduced clock-making and linenweaving to England by supporting the immigration of foreign artisans (Curtiss, 1912, p. 46). Moreover, the mercantilist legislation of Richard II was not 'merely haphazard'. Successive petitions to Parliament and the report of a Royal Commission on trade demonstrate that the merchants of the day were clear that 'they were laying the foundations of the famous mercantile system'. His successive parliaments adopted the three principal planks of later mercantilists: favouring natives and discriminating against foreigners, a policy favouring English shipping, and bullionist measures. Under pressure from English traders, Richard II ended the privileges enjoyed by Hanse traders in England and, at the same time, forced the League to admit the principle of reciprocity in its dealings with English merchants (Cunningham, 1889, p. 215; Palais, 1959, pp. 852-65).

It was clear to the earliest mercantilists that the Italian cities and the Dutch Republic owed their wealth and power not to Nature - they had few natural advantages other than their

\footnotetext{
${ }^{8}$ At this time, England specialised in the production and export of primary goods, foreign traders managed nearly all of its foreign trade and even some of its domestic trade, and Englishmen owned few ships.
} 
location - but to the advanced state of their arts. ${ }^{9}$ Implicitly, if not explicitly, the mercantilists placed all economic activities into three categories, anticipating the three-fold taxonomy of A. G. B. Fisher and Colin Clark, viz. primary, secondary and service sectors (Kenessey, 1987, p. 361). In England's Treasure by Foreign Trade, Thomas Mun (1664[1903], pp. 9, 98, 102-103) divides the economy into two sectors, Natural and Artificial. The Natural consists of the products of agriculture and the extractive sectors; they include, "Fleece wools, iron, lead, tynn, saffron, corn, victuals, hides and wax and other natural Endowments." In turn, the Artificial breaks down into "manufactures and industrious trading with forraign commodities..." We have here the distinction between manufactures and one class of services - shipping, insurance, buying, packaging, warehousing, selling, lending, and long-term investments associated with foreign trade - that the mercantilists valued greatly. Mun attributes Netherlands' prosperity to its foreign commerce and control of fisheries in the North Sea.

The mercantilist literature contains another taxonomy of economic activities based on the contributions they make to social wealth, where wealth consists of the use-value created by different activities (Perrotta, 2004, Ch. 9). Some writers classified the different occupations as productive or unproductive; others placed them under three headings, directly productive, indirectly productive, and unproductive. The distinction between productive and unproductive activities depended on three criteria: whether they produced physical goods or services, whether these goods were durable or perishable, and whether they served essential needs or were luxuries. Some services that supported the production of physical goods were seen as indirectly productive.

In order to augment domestic productive activity through international trade, the mercantilists examined the 'productive potential' of exports and imports, that is, their ability to serve as sites of productive activity (Perrotta, 2004, Ch. 10). Raw materials possess the greatest productive potential but this is exhausted as they undergo processing into finished goods. If the object of a country's trade policy is to expand domestic value-added in different lines of production, it should import goods that have the greatest productive potential, and export goods that have fully exhausted their productive potential. This would allow it to capture the greatest amount of value-adding productive activity in manufactures, transportation, shipping, storage, and commerce.

The mercantilists also ranked the contributions the different arts made to production, exports, employment, military power, people's aptitudes and the arts of civilization. Manufacturing was always superior to agriculture, and trade stood above manufacturing. ${ }^{10}$ 'There is much more to be gained by Manufacture than Husbandry;' wrote William Petty (1691[1899], p. 256), and 'by Merchandise than Manufacture....' Since the early seventeenth century, writes Sophus Reinart, mercantilists have maintained that 'there was something revolutionary about the manufacturing process, and that one should specialize in competitively importing raw materials and exporting finished goods' (emphasis added) (Serra, 1613[2011], p.3). It is worth noting that the advantages of manufacturing - and policies in support of manufacturing - were already commonplace during the fourteenth century in the Italian, German, Flemish and Dutch city states. 'In the majority of cases,' writes Carlo Cipolla (1963, p. 413), 'there was a conscious effort to industrialise. At the beginning of the fourteenth century the conviction was widespread that industry spelled welfare. In a Tuscan statute of 1336,

\footnotetext{
${ }^{9}$ Writing in 1565, John Hales (1581), an English cleric and theologian, recognised that the prosperity of Venice was owing to her export of manufactures (Reinert, 2003, p. 3). Similarly, Thomas Mun (1664[1903], p. 13) wrote, in 1621 (published in 1664), about how foreign trade had been the 'chief means' of raising Venice, Genoa and Holland to prosperity. Geoffrey Cymcox, the editor and translator of Giovanni Botero (1613[2012], p. xxxiii), thus describes Botero's thinking on the greatness of cities: 'A city that is a center of manufacturing and is endowed with an industrious population will be great and prosperous, as the cities of Flanders and northern Italy amply demonstrate.'

${ }^{10}$ According to the mercantilists, Lars Herlitz (1993, pp. 92-93) writes, 'the labor of crafts and manufacturing was more productive, or at least capable of becoming more productive, than that of agriculture.'
} 
statements may be read which might have been written by the most modern upholders of industrialisation in the twentieth century. ${ }^{11}$

The superior dynamism of manufacturing stems from its inherently greater scope for product innovation, its ability to endlessly shape, reshape, combine and recombine the products of nature. In 1588, the Italian writer, Giovanni Botero (1613[2012], p. 43), wrote that manufacturing surpasses the primary sector in contributing value-added because the things made by skilled human hands are far more numerous and costly than those produced by nature, for nature furnishes the material and the subject, but human skill and cleverness impart to them their inexpressible variety of forms.' He then proceeds to offer several examples of how manufactures transform crude materials - wool, silk and marble - into 'manifold and varied' artificial objects (Keller, 2012, p. 7). Similarly, Thomas Mun (1664[1903], p. 17) writes, ' '...we know that our natural wares do not yield us so much profit [value-added] as our industry.' He also offers a list of the products that are shaped from one primary product, iron ore. After the ore is 'digged, tried, transported, bought, sold,' it is 'cast into Ordnance, Muskets, and many other instruments of war for offence and defence, wrought into Anchors, bolts, spikes, nayles and the like, for the use of Ships, Houses, Carts, Coaches, Ploughs, and other instruments for Tillage. ${ }^{, 12}$

Several mercantilists were aware of increasing returns in manufacturing and commerce due to the greater scope they afforded to division of labour. William Petty offers examples of division of labour in textiles, ship-building, trade by sea, and watch-making; Henry Martyn points to division of labour in ship-building, textiles and watch-making; Ernst Ludwig Carl saw this principle at work in all the trades (Sun, 2012, pp. 40-46). However, Antonio Serra (1613, p. 121), an Italian writer of the early seventeenth century, offers the clearest statement of increasing returns in manufacturing. In manufacturing, he writes, 'it is possible to achieve a multiplication of products, and therefore of earnings. The same cannot be done with agricultural produce, which is not subject to multiplication. If a given piece of land is only large enough to sow a hundred tomoli of wheat, it is impossible to sow a hundred and fifty there. In manufacturing, by contrast, production can be multiplied not merely twofold but a hundredfold, and at a proportionately lower cost' (emphasis added). An Italian philosopher of the eighteenth century, Ferdinando Galiani, sums up Antonio Serra's insight in a few words: 'Manufactures increase with the number of arms you put in, while agriculture decreases' (Serra, 1613[2011], p. 5).

One of the earliest statements of the principle of cumulative causation may also be found in Serra (1613[2011], p. 127). Venice owes its prosperity, he writes, to 'a combination of two accidents, each of which lends force to the other.' The two accidents are the multiplicity of its manufactures and its extensive trade with other parts of Italy as well as with Asia and the rest of Europe. The number of people attracted to Venice by 'its extensive trade and its geographical location is increased still further by the number of businesses, and the number of businesses is increased by the extensive trade, which is itself increased by the number of people who come to the city.' This succinct statement of cumulative feedbacks between the 'number of businesses' and trade carries us beyond Adam Smith's (1776[1937], p. 17) statement that the 'division of labor is limited by the extent of the market.' It explicitly spells out connections that remain implicit in Adam Smith.

Manufacturing enjoys several additional advantages over agriculture, according to Serra (1613[2011], p. 121). Unlike agriculture, it is not hostage to the weather; its products are more storable and, hence, easier to export to distant places. Manufactures also 'yield much higher earnings than agricultural produce.' 'This can be seen,' he writes, 'especially in the

\footnotetext{
${ }^{11}$ Quoted in Issawi (1996, p. 239).

${ }^{12}$ In agriculture too, cross-breeding and culling are capable of producing new varieties of plants but, until quite recently, these processes were very slow compared to the fabrication of new products in the different branches of manufacturing.
} 
production of woollens, especially the finer fabrics, in the production of linen, silk, weapons, paintings, sculptures, books, and all the medicinal drugs, as well as an infinity of other things' (emphasis added). The variety of products in manufacturing also insures it against shifts in demand: declining demand in some activities is likely to be offset by increases in others.

Some mercantilist writers have also examined the contrary effects which natural and artificial wealth produce on the character of a people and on civilisation in general. Thus Mun (1664[1903], pp. 98-99, 112) argues that since the wealth produced in agriculture is 'always ready and certain, so doth it make the people careless, proud, and given to all excesses...' Although England's rich soil produces plenty, it also 'makes us a people not only vicious and excessive, wasteful of the means we have, but also improvident and careless of much other wealth that shamelessly we lose [such as in fishing]... whilest in the mean time (through lewd idleness) great multitudes of our people cheat, roar, rob, hang, beg, cant, pine and perish...' On the other hand, manufactures and commerce 'enforceth Vigilancy, Literature, Arts and Policy'.

Mercantilists were motivated not only by wealth-creation for its own sake, but also by the forms of wealth they sought, and their wealth-creation policies also advanced the power of the state (Fontanel et al., 2008). We know that their quest for gold was no fetish: as generalised purchasing power, gold could pay for mercenaries, ships and other provisions of war, especially when these expenses were incurred overseas or wars had to be fought at short notice. 'In war,' writes Fernand Braudel (1992, p. 547) while discussing mercantilist policies in early modern Europe, 'gold or silver coins were as indispensable as bread'. The growth of manufacturing and commerce could enhance state power through three other channels. To the degree that they stimulated economic growth, they expanded the country's tax base and, therefore, the state's capacity to secure advantages for its own nationals through military power. A large and diverse manufacturing sector could supply most of the state's needs for arms, munitions, and clothing. Finally, a country's fleet of trading ships (already armed) could be easily diverted to fighting wars.

\section{Physiocracy}

'The earth is the mother of all our goods' (Quesnay, 1759[1970], p. 13). ${ }^{13}$

Although no country had pursued mercantilist policies longer or more assiduously than Britain, the first theoretical reaction to it was elaborated by a French school of economics, Physiocracy, that was influential in France over two brief periods, 1763-70 and 1774-76.

In opposition to the dirigisme of mercantilists that promoted manufactures and commerce, the Physiocrats supported laissez-faire and regarded agriculture as the only productive sector in the economy. In contrast to the mercantilist framework of complex commodities - with variable consequences for growth, state power, and civilisational arts - the Physiocrats took a streamlined view of the economy that consisted of two sectors, agriculture and non-agriculture, which differed in only one significant respect. Agriculture alone is 'productive' since it produces a surplus over and above the costs of labour and capital employed in this sector. Artisans and traders are 'sterile' since they merely reproduce what they consume.

Agriculture is to the economy, the Physiocrats claimed, as the heart is to the circulatory system. The surplus generated in agriculture is the return to land that only enters agricultural production. Hence, this surplus accrues to the landlords or proprietors. Artisans and traders are supported by a part of this surplus, viz. the food and raw materials they acquire from farmers in

\footnotetext{
${ }^{13}$ Quoted in Moore (2013, p. 677).
} 
exchange for their manufactures and services. In other words, all the three classes of society the farmers who rent land from its owners for cultivation, the artisans (including traders), and the proprietors - are supported by agriculture. Agriculture is the engine of the economy.

The twin policy pillars of the Physiocratic policy - a single tax on land and laissez-faire - flow directly from their characterisation of commodities. ${ }^{14}$ The landlords paid the single land tax since they received all of the surplus produced in agriculture; as a 'sterile' class, any taxes imposed on artisans and traders would be transferred to the landlords. A single tax also had the merit of greatly simplifying the tax system and, therefore, reducing the cost of administering taxes. The Physiocrats also expected that laissez-faire would increase agricultural incomes. The removal of internal barriers to trade would create a single national market for agriculture: and this would increase agricultural production by concentrating production in regions with the lowest costs. At the same time, the rising price of corn under free trade would encourage farmers to utilise their lands more efficiently. Laissez-faire would also incentivise proprietors to increase investments in a variety of land improvements, and thereby increase the agricultural surplus.

The advocacy of laissez-faire by the Physiocrats may be seen as a pushback by the landowning elites against the mercantilist policies that had dominated France during the reign of Louis XIV. ${ }^{15}$ According to Norman Ware (1931, p. 618), Physiocracy accommodated the 'special needs of a new landowning class...The problem of these new landowners was to rid themselves of the innumerable taxes of the ancien regime which fell of necessity upon the land and made profitable farming impossible. Thus the single fixed tax on the net product of the land and freedom of trade in grain were their basic economic reforms.' It was also part of a larger movement in the social and natural sciences which sought inspiration from the order and harmony in nature (Spiegel, 1983, p. 185).

The Physiocrats' redefinition of commodities offers an early and transparent example of how economic theory serves the interests of powerful classes. In order to privilege the new capitalist land-owners, they identified agriculture as the only sector that produces a surplus. They ignored the rent earned by manufacturing and commercial enterprises due to market power - conferred by innovations or increasing returns to scale - and their proximity to markets, raw materials, and waterways. Finally, if agriculture earns a surplus because of fixed land, this also subjects labour in this sector - as Ann-Robert-Jacques Turgot pointed out - to diminishing returns; while manufacturing and commerce are more likely to enjoy increasing returns to scale because of their greater scope for division of labour.

\section{Classical Economics}

'It is a very common clever device that when anyone has attained the summit of greatness, he kicks away the ladder by which he has climbed up, in order to deprive others of the means of climbing up after him. In this lies the secret of the cosmopolitical doctrine of Adam Smith...' (List, 1827[1909], pp. 295-6).

Although classical economists retained elements of complexity in their discussions of economic growth, they took the opposite approach when making the case for laissez-faire and free trade. Quite simply, their ideological quest was not compatible with complex commodities.

\footnotetext{
${ }^{14}$ The Physiocrats did not account for the presence of increasing returns to scale in manufacturing and commerce, or suggest that these activities generated external economies.

${ }_{15}$ Mark Blaug (1985, p. 24) writes, 'Physiocracy, as Adam Smith suggested, should be understood as a reaction to the mercantilist policies of Colbert during the reign of Louis XIV.'
} 
Several of the leading classical economists embraced the distinction - common in mercantilist writings - between 'productive' and 'unproductive' activities. The former produced value that was fixed in tangible goods and hence could be stored; the latter produced intangible services that could not be stored or traded at a distance. This is not an empty distinction. Unproductive labour cannot be used to mobilise labour in the future: it does not fix itself in tangible goods. Hence, Adam Smith concludes correctly that the standard of living in any economy will depend on 'the proportion between the number of those who are employed in useful labour, and that of those who are not so employed' (Smith, 1776, pp. 314-15, Iviii). Despite criticism from some quarters, Blaug (1985, p. 55) writes, 'Smith's distinction was retained by all the leading classical economists... and it was handed down in the end to Marx to become the basis of the present-day Soviet national income accounting.'

The classical economists also built their theories of the macro economy and income distribution on a structural distinction between agriculture and manufacturing. Production in agriculture used both labour and land; and since land was assumed fixed, this produced a tendency towards diminishing returns in agriculture. ${ }^{16}$ On the other hand, production in manufacturing depends only on labour: hence, this sector is not subject to diminishing returns. ${ }^{17}$ This division of the economy into two sectors with different production characteristics - together with a population that rises and falls as wages rise above or fall below the subsistence level defines an economy that always returns to equilibrium at subsistence wages. As wages rise or fall in response to external shocks, the population adjusts to restore the economy to a new equilibrium at the subsistence wage (Clark, 2007, Chapter 1).

Adam Smith made much of another distinction between manufacturing and agriculture, the first supported a more extensive division of labour. ${ }^{18}$ This distinction was vital to Adam Smith's theory of economic growth: since division of labour is the chief source of productivity gains in the economy. ${ }^{19}$ Within manufacturing too, the division of labour differs from one branch to another. 'There are perhaps no manufactures,' writes Adam Smith (1776[1937], p. 243), 'in which the division of labor can be carried further, or in which the machinery employed admits of a greater variety of improvements, than those of which the materials are the coarser metals [iron and steel].' His description of the extensive division of labour in a pin factory nicely illustrates this.

This asymmetry between manufactures and primary production raised intractable problems for the classical theory of trade. Countries that enter world markets with advantages in manufacturing will deepen these advantages. Further, because of external economies produced by expanding manufactures, these countries will extend these advantages to other related lines of manufacturing even in the face of rising wages. ${ }^{20}$ In the long run, therefore, free trade will concentrate manufactures in a few countries - conceivably in one country - while all other

\footnotetext{
${ }^{16}$ With the exception of Antonio Serra, mercantilist writers did not explicitly recognise diminishing returns in agriculture, but their emphasis on manufacturing, export of manufactures, and acquisition of colonies - as sources of raw materials and outlets for a growing population - appears to be based implicitly on the diminishing capacity of agriculture to support a growing population. The export of manufactures could feed a growing population by paying for imports of food and raw materials (Spengler, 1988, p. 6).

${ }^{17}$ The inclusion of capital in manufacturing did not affect this result. Since equipment used by workers still formed a small part of the costs of production, this could be readily expanded to equip each new worker in manufacturing. This ensured fixed returns to a labourer equipped with the tools of his trade.

${ }^{18}$ John Stuart Mill $(1885$, pp. 124, 557) makes the same point. 'The division of labor is also limited, in many cases,' he writes, 'by the nature of employment. Agriculture, for example, is not susceptible of so great a division of occupations as many branches of manufactures, because its different operations cannot possibly be simultaneous.' He adds that this asymmetry also exists between other extractive industries and manufacturing.

${ }^{19}$ Adam Smith opens chapter 1, Book One, of his classic with a succinct statement connecting productivity of labour to division of labour: 'The greatest improvements in the productive powers of labor, and the greater part of the skill, dexterity, and judgment, with which it is anywhere directed, or applied, seem to have been the effects of the division of labor.'

${ }^{20}$ This flows from two observations: (a) a positive feedback between increasing returns and size of markets, and (b) a stronger tendency towards increasing returns in manufactures than in primary production. For a fuller discussion of this issue, see Alam (2000, pp. 51-52).
} 
countries specialise in primary goods. Adam Smith's dynamic theory of trade did not make a universal case for free trade. On the contrary, it made the case for lagging countries to protect their manufactures until they too could share in the dynamic gains from the expansion of manufactures.

Adam Smith's theoretical case for free trade faced another embarrassment: it was contradicted by historical evidence, indeed by the historical evidence presented by Adam Smith himself. If a country's economic prospects are best advanced by a policy of free trade, how are we to explain Britain's rise to economic eminence (Alam, 2000, pp. 52-53; Chang, 2003, pp. 19-24)? Adam Smith (1776, p. 393) pointedly acknowledges that since the mid-16th century, England had led Europe in its devotion to mercantilist policies. He writes that since 'the beginning of the reign of Elizabeth... the English legislature has been peculiarly attentive to the interests of commerce and manufactures, and in reality there is no country in Europe, Holland itself not excepted, of which the law is, upon the whole, more favourable to this sort of industry. Commerce and manufactures have accordingly been continuously advancing during all this period' (italics added). Elsewhere, he maintains that 'manufactures and commerce together, have given birth to the principal improvements in agriculture' (italics added) (Smith, 1776, p. 360). Instead of making the case for free trade, familiarity with Britain's rise to economic preeminence would persuade lagging countries to imitate her success by protecting their manufactures and commerce. In order to discourage the rest of the world from following her example, Britain needed a universal theory of free trade, one that argued that free trade was advantageous for all countries. In the early nineteenth century, two British economists, Robert Torrens and David Ricardo, answered this call.

David Ricardo steered away from the complexities that had frustrated Adam Smith's attempt at formulating a theory of universal free trade. In his famous numerical example, England and Portugal produce wine and cloth with constant unit labour costs (Blaug, 1985, p. 123). ${ }^{21}$ In other words, chapter eight of his Principles of Political Economy proceeds by stripping commodities of all but one of their attributes, viz. their different labour costs. Labour is also immobile between countries. It did not matter that David Ricardo's theory of growth and distribution was built on diminishing returns to labour in agriculture, so that the unit labour cost of wine would rise with output. Wine and cloth - proxies for agriculture and manufacturing - now became nearly homogenous activities; they required only labour for their production under conditions of constant returns to scale. Commodities in the Ricardian world are completely defined by a single number: their fixed labour costs.

This redefinition of commodities - produced under conditions of constant labour costs allowed Ricardo to exclude time from his framework. In addition, since labour could not move between countries, he could now examine a one-off impact of the opening of trade on the allocation of labour within each country. Under these conditions, later economists concluded that trade would produce complete specialisation in each country: it would also improve each country's welfare. Quite conveniently, then, through an extreme evisceration of commodities, David Ricardo had avoided dealing with all the big questions regarding the impact of trade on division of labour, technology, costs, tastes, income distribution, savings, capital formation, class conflicts, national sovereignty and population growth. On this daring disappearing act was founded perhaps the most venerable - but tautologically true - result in the entire canon of economics, viz., the theory of comparative advantage.

It should be noted that the assumption of constant costs had already been introduced into the theory of markets by Adam Smith. 'If we look carefully at Smith's examples of price determination,' wrote Blaug (1985, p. 41), 'we notice that he always assumes implicitly that the

\footnotetext{
${ }^{21}$ Most economists accept this reading of the numerical example David Ricardo (1817[1996], pp. 94-95) employs to develop his theory of trade. Among others, Roy Ruffin (2002) has contested this interpretation.
} 
'natural price' of a commodity does not vary with its rate of output. In other words, he assumes that the industry in question produces under conditions of constant costs...; cost per unit remains constant regardless of the level of output.' Did Adam Smith begin the practice of choosing the assumptions to produce the right results?

\section{Neoclassical Economics}

'Too large a proportion of recent 'mathematical' economics are mere concoctions, as imprecise as the initial assumptions they rest on, which allow the author to lose sight of the complexities and interdependencies of the real world in a maze of pretentious and unhelpful symbols' (Keynes, 1936, pp. 272)

Initiated by the Physiocrats, the evisceration of commodities underpins Adam Smith's theory of natural prices and becomes explicit in David Ricardo's universal theory of free trade. It was finally carried to its logical conclusion in the 1950s with the formalisation of the competitive paradigm by Kenneth Arrow and Gerard Debreu (1954) and others.

In the late nineteenth century, the marginalists set the stage for the formalisation of the competitive paradigm by focusing on the purely allocative functions of markets. Thus, for Stanley Jevons, the task of economists was to determine - in the presence of a fixed labour force and given tastes and technology - 'the mode of employing their labor which will maximise the utility of the produce' (Blaug, 1985, p. 295). Once this static framing of the marginalists' enterprise was accepted, determining the conditions under which markets simultaneously attain a unique and stable equilibrium became the Holy Grail of neoclassical economics. Increasing returns activities were excluded since this would greatly complicate this quest. ${ }^{22}$ Only the assumption of constant returns to scale offered the chance (though not the certainty) of ruling out multiple equilibria. ${ }^{23}$ The imperative of constant returns to scale also led to the disappearance of land from the neoclassical account of production. The differences between any two goods could now be reduced to one dimension: the ratio in which they combined capital and labour. Capital was also taken to be fully malleable, so that machinery and buildings from a declining textile industry could be converted into blast furnaces for use in an expanding steel industry.

Constant returns to scale was a vital element of the competitive paradigm that was used to justify inequalities arising from non-property incomes. It was not too difficult to show that competitive firms eager to maximise profits paid wages equal to the marginal product of labour. Certainly, this result depended on the assumption - rarely satisfied - of perfectly smooth substitutability between labour and capital in production; but such difficulties have never stopped neoclassical economists from introducing clever assumptions as long as they produced the desired results. Phillip Wicksteed placed the marginal productivity theory of factor prices on a pedestal when he showed that under the assumption of constant returns to scale, payments to factors fully exhaust the total product. There could now be no turning away from constant returns to scale: it became an indispensable ingredient in the theoretical armour of neoclassical

\footnotetext{
${ }^{22}$ Some of these difficulties are stated succinctly by Geoffrey Heal (1998: abstract). 'Recognizing increasing returns,' he writes, 'affects the possibility of market equilibrium, can introduce sticky prices, causes economies to lock-in to inefficient technologies and introduce path-dependence, affects the possibility of continuing growth, produces problems for regulators, and changes our conception of the effects of international trade. All in all, increasing returns can change quite radically our view of how the economy operates.'

${ }^{23}$ Alam (2013) has shown that the market equilibrium described by the competitive paradigm is inconsistent with constant returns to scale.
} 
economists. $^{24}$

Two Swedish economists, Eli Hecksher (1919[1950]) and Bertil Ohlin (1933[1950]), used this framework to reformulate Ricardo's theory of comparative advantage. They would explain comparative advantage in terms of differences between countries in their factor endowments, although they had a more capacious understanding of factors of production than the neoclassical economists. In the early post-war years, Paul Samuelson $(1948,1949)$ incorporated the factor-endowment theory of trade into an explicitly neoclassical framework that only allowed for two factors of production, capital and labour; he also assumed that production technology was a public good that was equally available to all countries in the world. Within this formal neoclassical framework, free trade among countries produced an extraordinary result: it equalised wages and the return to capital across all countries no matter how far apart their wages and capital returns were before trade. This was the ultimate defence of free trade. It did not matter whether a country exported computer chips or potato chips; free trade would produce convergence of wages and returns to capital across all countries. Once stripped of all but one of their differences, commodities can be used to support magical results.

\section{Challenging Laissez-faire Economics}

Opposition to laissez-faire has come from lagging countries eager to develop indigenous capacity in manufactures, construction, finance, commerce, shipping, education and research and development.

In the interest of economy, much of our discussion will focus on the arguments of two writers, Alexander Hamilton (1791[1913]) and Friedrich List (1827[1909]), who advanced the protectionist cause in the United States ${ }^{25}$ Although List was a German national, he developed his protectionist ideas while he was in the United States from 1825 to 1830 . The articles he published in support of protectionist policies - during his stay in the United States - were published as Outlines of American Political Economy. Hamilton and List argued that an economy that combines manufactures with agriculture would produce greater prosperity than one which specialises in agriculture. While they were interested in promoting a better utilisation of existing resources, their chief interest lay in emphasising the superior contributions that manufacturing makes to the development of a country's productive powers. In other words, while Smith and Ricardo had homogenised commodities, these writers took a leaf from the mercantilists and insisted on demonstrating the multifarious differences between manufacturing and agriculture.

Hamilton's (1791, pp. 11-17) Report on Manufactures built its case for protection primarily around the greater scope for division of labour in manufacturing. Adam Smith recognised three sources of productivity gains from division of labour, viz. improvements in skills, mechanisation, and savings in time; to this list, Hamilton added several more. The diverse talents of a population are more likely to find their best uses in manufacturing with the variety of demands it makes on knowledge, skills and aptitudes. For the same reason, manufacturing is more likely to offer jobs that match the capacities of women, children, and workers faced with a temporary slack in their regular work. With artificial lighting it allows work to be carried on at night; and, protected from the elements, it allows work to occur year-round. Manufacturing also benefits agriculture by creating more stable markets for its products and, as new manufactures

\footnotetext{
${ }^{24}$ For an excellent review of the place of constant returns to scale in the thinking of the leading classical and neoclassical economists, see John Hicks (1989).

${ }^{25}$ According to one source only six of the fifteen leading American economists during the half century from 1820 to 1870 threw their weight behind the promotion of manufactures (Fetter, 1943, p. 53). Although outnumbered, the protectionist writers carried the day.
} 
are introduced, it creates demand for new agricultural products. On the whole, Hamilton's Report presents a more comprehensive account of the advantages of manufacturing than Adam Smith's Wealth of Nations.

List carries Hamilton's analysis of the advantage of manufacturing to a deeper level. He focuses his discussion on the 'productive powers' of an economy or its 'powers of producing wealth'. He breaks down a country's productive powers into three components: its natural, material and mental capital. Natural capital is the equivalent of 'land' in the writings of classical economists; material capital consists of machines, inventory and raw materials; and mental capital is a comprehensive category that includes human, scientific, cultural, social, institutional and political capital. It is mental capital that possesses the greatest potential to propel an economy forward on all fronts. List also emphasises the positive feedbacks that operate among the three forms of capital in different economic activities. ${ }^{26}$

In List's system, the superiority of manufacturing over agriculture and commerce derives from its greater ability to generate mental capital. The classical economists did not comprehend 'how greatly the nature of the agricultural productive power differs from the nature of the manufacturing productive power' (List, 1841, p. 148). List was determined to rectify this fundamental error in classical economics in a most exhaustive manner; he devotes nine of the seventeen theoretical chapters in his book to discussions of the powers of manufacturing to stimulate progressive changes in every department of society and economy. 'Manufactories and manufactures,' he writes, 'are the mothers and children of municipal liberty, of intelligence, of the arts and sciences, of internal and external commerce, of navigation and improvements in transport, of civilisation and political power. They are the chief means of liberating agriculture from its chains, and of elevating it to a commercial character and to a degree of art and science, by which the rents, farming profits, and wages are increased and greater value is given to landed property.' On the contrary, agriculture holds back a country's economic development. In a condition of 'merely agricultural industry, caprice and slavery, superstition and ignorance, want of means of culture, of trade, of transport, poverty and political weakness exist' (List, 1841, pp. 141-142).

In the 1930s, two economic historians unintentionally challenged the world-view of eviscerated commodities. David Ricardo had reduced differences between commodities to their labour coefficients; and neoclassical economists had narrowed this down to capital-labour ratios. A.G.B. Fisher and Colin Clark marshalled statistical data to present a very different view of economic activities. They divided the economy into three rather well-defined sectors primary, secondary and tertiary - whose output and employment shares in the economy followed rather different trajectories in countries that had experienced sustained growth in per capita incomes. These different trajectories in the shares of the three sectors could be explained primarily by different income elasticities of demand and growth rates of labour productivity in the three sectors. Although these explanations contradicted the assumptions of homogenised commodities, the neoclassical economists did not notice.

Some two decades after Fisher and Clark explored the implications of the different attributes of primary, secondary and tertiary activities for long-term changes in the structure of an economy, the neoclassical economists extended their paradigm into the new territory of growth economics. In the 1950s, Robert Solow (1956) and Trevor Swan (1956) developed theories of growth for an economy that produced one commodity under conditions of constant returns to scale. Their neoclassical growth theory predicted convergence in the levels of per capita income across all countries. It did not matter that the economic history of the past century

\footnotetext{
26 'The augmentation,' writes List (1827[1909]): 228), 'of the national material capital is dependent on the augmentation of the national mental capital, and vice versa.' A similar reciprocity exists between 'material agricultural capital' and 'material manufacturing capital'; and 'material commercial capital acts everywhere as an intermediary, helping and compensating between both."
} 
directly contradicted this prediction. This new growth theory engaged the attention of many of the leading economists for at least two decades.

Starting in the 1940s, the eviscerated commodities of neoclassical economics faced a new theoretical challenge from development economics, a new branch of economics called forth by the imperatives of promoting economic growth in the lagging countries of Asia, Africa, Latin America and Eastern Europe. Encouraged by the Keynesian rejection of neoclassical economics, several economists began building their analysis of economic development on a complex view of commodities and markets. The early pioneers of development economics chief among them Paul Rosenstein-Rodan, Ragnar Nurkse, Tibor Scitovsky, Hans Singer, Raul Prebisch, W. Arthur Lewis, Albert Hirschman and P. C. Mahalanobis - preferred to examine the problems of development under conditions that better approximated the real world (Seers, 1984). Among other things, they observed significant differences across industries in their conditions of employment, the technologies they used, the demand conditions they faced, their ability to generate positive externalities, the rates at which they produce learning by doing, the pressures they create for savings and investments, the strength of their forward and backward linkages, the indivisibilities in their operation, the pressures they produce for worker discipline, etc. In comparing the growth-enhancing attributes of the manufactures and agriculture, these economists concluded that the manufactures possessed by far the greater potential for injecting dynamism into the moribund economies that had long been trapped in primary production with traditional technologies. In other words, they turned the world of neoclassical economics on its head: they were closer in their methods to the mercantilists and the protectionist economists of the nineteenth century.

Upon this more realistic conception of commodities, the development economists supported an interventionist role for governments in the backward economies of the post-War era. It is doubtful however if the newly formed governments in the former colonies waited for the approval of economists in implementing their interventionist programs in support of economic development. They could not sit on the sidelines in the face of rising demand in the newly independent countries for jobs, education, industrialisation, electricity, roads, dams, the loans for private investment in infant industries. For the most part, the development economists provided the rationale for what the governments in developing countries were already doing or would have done on their own.

Starting in the late 1970s, a few neoclassical economists - led by Paul Krugman (1979) and others - took upon themselves the task of explaining intra-industry trade flows that made up the bulk of trade between advanced countries (Jomo and Arnim, 2008). The explanation was fairly straightforward once they jettisoned the assumption of constant returns to scale. In a world of increasing returns to scale (IRS), a country's competitive advantage may arise from a variety of accidents. International trade then deepens these advantages. IRS also makes it unlikely that any country - even a big country - will develop competitive advantage in all the lines of a given branch of manufacturing. Throw into this picture product branding and diversity of tastes in a population and you have an explanation of intra-industry trade flows. Once these intuitive ideas were packaged in equations a 'new' trade theory was born. At last, mainstream economists had embraced some elements of the complexity of commodities that were part of the repertoire of mercantilists and their intellectual heirs. Strategic trade policies had now acquired a measure of theoretical respectability in academia. Strangely, however, the rise of the new trade theory was followed by the triumph of the neoliberal paradigm that was squarely rooted in neoclassical orthodoxy. The great powers were not about to jettison their interests just because some MIT economists had made mercantilism mathematically respectable. 


\section{Concluding Remarks}

A review of economic discourse since the $16^{\text {th }}$ century - primarily in Western Europe - reveals two opposite approaches to the study of economies, which may be described as dirigisme and laissez-faire. Setting them apart is the manner in which they incorporate commodities into their discourse.

The older dirigiste approach - dating back to the sixteenth century - embraces the complexity of real-world commodities, each endowed with properties that may generate widely divergent consequences for growth, market structures, state formation, and levels of civilisation. Stated succinctly, this approach arranges commodities in a hierarchy, based on their growthand rent-augmenting effects (GREs). The GREs of commodities are likely to rise with increasing returns to scale, capital-intensity, skill intensity, research and development expenditures, technology and social spillovers, etc. Under laissez-faire, lagging countries are likely to be pushed into industries with low GREs, while advanced countries increase their share of industries with high GREs. Hence, the choice of dirigisme by lagging countries that seek to catch up to the leading economies.

Advanced in opposition to the dirigiste approach, the second approach seeks support for its laissez-faire stance by stripping commodities of all but one of their attributes, viz. their capital intensity in production. This approach was first elaborated by Adam Smith to rationalise the global interests of Britain, already the most advanced economy in the 1770s, by making the case for the superiority of free trade for all countries. Underpinned by a battery of assumptions about technology, tastes, rationality, information, transaction costs, property rights, and market structures, free markets bring about an 'efficient' allocation of resources. Since efficiency is the chief desideratum in this approach, and this is automatically achieved by markets, there remains nothing for governments to do. Only as an afterthought, since markets cannot produce them, governments are allowed to supply public goods.

A survey of economic thought and economic policy over the past half a millennium reveals some fairly stable patterns in most sovereign countries between their economics, economic policies and levels of development. ${ }^{27}$ The leading economies, with the most advanced knowledge and technology infrastructures, promote - and impose when they can free trade policies in the rest of the world, even as they continue to deviate from their own precepts when this is deemed necessary for economic or political reasons. On the other hand, sovereign lagging countries employ dirigiste policies in order to increase their global share of high-end industries (with high GREs), at least until such time as they become globally competitive.

Other patterns too are worth noting. On account of the strong synergies between highend industries and military power, the two often grow together. Historically, the leading economies - in some cases, notwithstanding their small population - have deployed powerful militaries to establish their imperium over lagging economies through a variety of devices, including trading outposts, colonisation with or without colonial settlements, Open Door treaties, installing governments of their choice, overthrowing 'unfriendly' governments, lending programmes, military sales, the use of soft power, etc. The objective of this imperium is clear: capture for their own corporations the most valuable resources and markets in lagging countries.

This suggests two corollaries. In periods when the power of advanced countries has been ascendant - from the early 1800s into the 1940s and, again, starting in the 1980s - most

\footnotetext{
${ }^{27}$ These patterns are unlikely to be observed in countries that are sovereign but whose dominant classes draw their income and power from primary sectors (and primary exports), especially when the labouring population is considered racially inferior to the land-owning and urban elites.
} 
lagging countries were forced into unequal economic relations with the advanced countries. On the other hand, when the imperium of the great capitalist powers has been in retreat - because their economies were hit by depressions, they were fighting among themselves, or they were challenged by the rise of communism - we observe the greatest spread of dirigiste policies across the lagging countries. Such a window opened up for about three decades after 1945, due to the decline of the three leading imperialist powers of the previous century, the rise of a new capitalist hegemon - the USA - and the challenge to global capitalism from the rise of Soviet Union.

\section{Acknowledgements}

I am grateful to Professors Cosimo Perrotta, Annalisa Rosselli (University of Rome Tor Vergata), and Reinhard Schumacher (University of Potsdam) for comments on the Economic Thought Open Peer Discussion forum that have helped greatly to improve the arguments and layout of this paper. All shortcomings of the paper are still mine.

\section{References}

Alam, M. S. (2000) Poverty from the Wealth of Nations Houndmills, England: Macmillan.

Alam, M. S. (2013) 'Constant Returns to Scale: Can the Market Economy Exist?' Real-World Economics Review, 64.

Arrow, K. J. and G. Debreu, (1954) 'Existence of an Equilibrium for a Competitive Economy.' Econometrica 22, 3, 265-290

Blaug, M. (1985) Economy Theory in Retrospect. Cambridge University Press.

Botero, G. (1588[2012]) On the Greatness and Magnificence of Cities. (Ed. and Tr.) Geoffrey Cymcox. Toronto: University of Toronto Press.

Braudel, F. (1992) The Wheels of Commerce: Civilization and Capitalism, $15^{\text {th }}-18^{\text {th }}$ Century. Berkeley, CA: University of California Press.

Chang, Ha-Joon (2003) Kicking Away the Ladder: Development Strategy in Historical Perspective. London: Anthem Press.

Cipolla, C. (1963) 'The Italian and Iberian Peninsulas.' In M. M. Postan, E. E. Rich and E. Miller (Eds.) Cambridge Economic History of Europe, Volume 3. Cambridge MA: Cambridge University Press.

Clark, C. (1940) The Conditions of Economic Progress. London: MacMillan.

Clark, G. (2007) Farewell to Alms: A Brief Economic History of the World. Princeton, NJ: Princeton University Press.

Close, A. J. (1969) 'Commonplace Theories of Art and Nature in Classical Antiquity and in the Renaissance.' Journal of the History of Ideas 30, 4, 467-86.

Close, A. J. (1971) 'Philosophical Theories of Art and Nature in Classical Antiquity.' Journal of the History of Ideas 32, 2, 163-84.

Cunningham, W. (1889) 'The Commercial Policy of Edward III.' Transactions of the Royal Historical Society 4, 197-220.

Curtiss, G. B. (1912). The Industrial Development of Nations, Vol. I. Binghamton, NY: George

B. Curtiss Publishers. 
Fetter, F. A. (1943) 'The Early History of Political Economy in the United States.' Proceedings of the American Philosophical Society 87, 1, 51-60.

Fisher, A. G. B. (1935) The Clash of Progress and Security. London: MacMillan.

Fontanel, J., J.-P. Hebert and I. Samson (2008) 'The Birth of the Political Economy or the Economy in the Heart of Politics: Mercantilism.' Defense and Peace Economics. 19, 5, 33138.

Hales, J. (1581) Compendious or Briefe Examination of Certayne Ordinary Complaints of Divers of Our Countrymen in These Our Dayes. London: Thomas Marshe.

Hamilton, A. (1791[1913]) 'Report on Manufactures: Communication to the House of Representatives.' Washington: 1913.

Heal, G. M. (1998) 'The Economics of Increasing Returns.' Columbia Business School, Working Paper Series in Money, Economics and Finance, PW-97-20.

Heckscher, E. (1919) 'The Effect of Foreign Trade on the Distribution of Income.' In H.S. Ellis (Ed.) Readings in the Theory of International Trade. Philadelphia: American Economic Association, 1950, 272-300.

Herlitz, L. (1993) 'Conceptions of History and Society in Mercantilism.' In Lars Magnusson. (Ed.) Mercantilist Economics. New York: Springer, 92-93.

Hicks, J. (1989) 'The Assumption of Constant Returns to Scale' Cambridge Journal of Economics. 13, 1, 9-17.

Hunt, E. K. (2003) Property and Prophets: The Evolution of Economic Institutions and Ideologies. Armonk, NY: M. E. Sharpe.

Issawi, C. (1996) 'The Economic Legacy.' In L. Carl Brown. (Ed.) Imperial Legacy: The Ottoman Imprint on the Balkans and the Middle East. New York: Columbia University Press.

Jomo, K. S. and R. Von Arnim (2008) 'Trade Theory Status Quo Despite Krugman.' Economic and Political Weekly, 3, 29-31.

Kaldor, N. (1981) 'The Role of Increasing Returns, Technical Progress and Cumulative Causation in the Theory of International Trade and Economic Growth.' Economie Appliquee. 4, 593-617. In F. Targetti and A. P. Thirlwall. (Ed.) The Essential Kaldor. New York: Holmes and Meier.

Keller, V. (2012) 'Mining Tacitus: Secrets of Empire, Nature and Art in the Reason of State.' British Journal of the History of Science, 45, 165/II, 1-24.

Kenessey, Z. (1987) 'The Primary, Secondary, Tertiary and Quaternary Sectors of the Economy.' Review of Income and Wealth, 33, 4, 359-85.

Keynes, J. M. (1936[2008]) General Theory of Employment, Interest and Money. New Delhi: Atlantic Publishers.

Krugman, P. (1979) 'Increasing Returns, Monopolistic Competition, and International Trade.' Journal of International Economics, 9, 469-79.

List, F. (1827[1909]) 'Outlines of American Political Economy.' In M. Hirst. (Ed.) Life of Friedrich List and Selections from his Writings. London: Smith, Elder \& Co.

Magnusson, L. (Ed.) (1993) Mercantilist Economics. Boston, MA: Kluwer.

Margaret, L. (1986) 'Art, Artifice and the Artificial in the Works of Francis Bacon. XVII-XVIII.' Bulletin de la Société d'ètudes Anglo-Americanes des XVIIe et XVIle siecles, 22, 7-18.

Mill, J. S. (1885) Principles of Political Economy. (Abridged and Edited by J. Laurence Laughlin.) New York: D. Appleton and Company.

Moore, J. A. (2013) Institutions and Ideas: Industrialization and the Making of Early American Trade Policy. Detroit: Wayne State University Dissertations. 
Mun, T. (1664[1903]) England's Treasure by Forraign trade. New York: Macmillan and Co.

Ohlin, Bertil. (1933[1966]) Interregional and International Trade. Cambridge, Mass.: Harvard University Press.

Palais, H. (1959) 'England's First Attempt to Break the Commercial Monopoly of the Hanseatic League, 1377-1380.' American Historical Review, 64, 4, 852-65.

Perrotta, C. (2004) Consumption as an Investment: I, The Fear of Goods from Hesiod to Adam Smith. London and New York: Routledge.

Petty, W. (1899) The Economic Writings of Sir William Petty. (Ed.) Charles H. Hull. Cambridge: Cambridge University Press.

Quesnay, F. (1759[1970]) The Economic Table. New York: Bergman Publishers.

Reinert, E. and S. Reinert (2011) 'Mercantilism and Economic Development: Schumpeterian Dynamics, Institution Building, and International Benchmarking.' OIKOS, 10, 1, 8-37.

Ricardo, D. (1817[1996]) On the Principles of Political Economy and Taxation. Amherst, NY: Prometheus Books.

Ruffin, R. J. (2002) 'David Ricardo's Discovery of Comparative Advantage.' History of Political Economy, 34, 4, 727- 48.

Samuelson, P. (1948) 'International Trade and the Equalization of Factor Prices.' Economic Journal, 58, 163-84.

Samuelson, P. (1949) 'International Factor-Price Equalization Once Again.' Economic Journal, 59, 181-97.

Seers, D. (1984) (Ed.) Pioneers of Development. New York: Oxford University Press.

Serra, A. (1613[2011]) A Short Treatise on the Wealth and Poverty of Nations. (Ed.) Sophus A. Reinert. London: Anthem Press.

Smith, A. (1776[1937]). An Enquiry into the Nature and Causes of the Wealth of Nations. New York: The Modern Library.

Solow, R. M. (1956) 'A Contribution to the Theory of Economic Growth.' Quarterly Journal of Economics, 70, 1, 65-94.

Spengler, Joseph J. (1988) 'History of Population Theories.' In Julian L. Simon. (Ed.) The Economics of Population: Classic Writings. New Brunswick: Transaction Publishers.

Spiegel, H. W. (1983) The Growth of Economic Thought. Durham, NC: Duke University Press.

Sun, Guang-Zhen (2012) The Division of Labor in Economics. London: Routledge.

Swan, T. W. (1956) 'Economic Growth and Capital Accumulation.' Economic Record, 32, 2, 334-361.

Uztariz, Geronymo (1724[1752]). The Theory and Practice of Commerce and Maritime Affairs. 2 vols. John and James Rivington, London.

Ware, N. J. (1931) 'The Physiocrats: A Study in Economic Rationalization.' American Economic Review 21, 607-619.

Weeks, S. (2007) 'Francis Bacon and the Art-Nature Distinction.' Ambix, 54, 2, 117-45. 